\title{
Leadership That Reinforces Learning: A Comparative Study between Manufacturing and Service Sector Organizations of Pakistan
}

\author{
${ }^{1}$ Rakhshan Ummar, ${ }^{2}$ Muhammad Ehsan Lodhi, ${ }^{3}$ Nosheen Khan
}

\begin{abstract}
The study being done in response to the high demand of making the organizations more supportive to encounter the abundant changes that occur and reoccur in the world of business. The role of leadership is undeniable, pervasive and overwhelming as "leadership that reinforces learning" is one of the building blocks of "learning organizations" this study will benefit the organizations to compare their potential to take the advantage of their leadership to embark on the journey of learning. At the same time it will serve the purpose of new domains in research to improvise leadership traits, styles and their real time utility. The most important variable in the third building block "leadership that reinforces learning" have been found to be the interaction of leaders with their subordinates, identify and ultimately resolve their ambiguities. The other variable found significant is the transfer of knowledge to others across the organizations. The result also reveals that both education as well as manufacturing sector lacks the active and effective role of leadership. It is concluded that education sector even lags behind the manufacturing concerns. It is therefore concluded that in order to make these sectors impart value to the society leadership be enhanced.
\end{abstract}

Key Words: Leadership, manufacturing sector, service sector, learning organizations.

\section{Introduction}

All organizations take a lead role to develop their leadership with modern business virtues, ingredients, combinations and align them to attain their "vision". An organization can only operate at a level at which its leadership operates, therefore the ceiling established by it must be constantly upgraded, amended and improved to make organization more effective to combat and respond to uncertainty("High Impact Leadership and Leadership and Learning Creates Sustainable Change"). The concept of high impact leadership should be spread to individual, interpersonal space, work and the world at large (Nel 2007). The founders of the learning organization Approach have found to be Peter Senge, Chris Agyris, Donal S.Hon and Magaret Wheatley. The approach of Growth and prosperity generated and harnessed by Peter Senge. With holds him as the "Father" of organization Learning (Dumaine 1994). Pakistan is by no means unaffected with the sweeping changes that are taking place in the economy at large and business which are the prime areas of interest for management related scholars. The basic concept underpinning this paper is "Leadership that reinforces learning"(Garvin, Edmondson et al. 2008). This study would focus the role of leadership in the textile sector and Education Sector in Faisalabad. The comparison will unfold the area of better performance and would enable both Sectors to improve there efficiency having better brains and better bread for Pakistan as well as other countries which can identify their business and macro aspects with Pakistan .One organization form each sector is taken as the sample of study. A portion of the tool-kit that was developed by David. A. Garvin. (Harward Business review March, 2008.) Used in his article whose title is "Is yours a learning Organization" is being used to analyze the role of leadership in Pakistan.

\section{Literature Review}

Learning is an ongoing process that challenges Status Quo (Argyris 1977) that is an introduction of "double loops learning as compared to single loop learning, it would only be intrinsic motivation and sense of an organization Stewardship felt by managers at all level to make them committed to continuous non-routine learning"(Slater and Narver 1995). The work of (Eraut 1995)to encourage the commitment to an innovative shift, "reflection in action" is both a consequence and cause of "surprise". When a traditional leader is subjected to conscious criticism and change, he may increase his capacity to contribute to significant organization learning. Margaret Wheatly's book "Leadership and the New Science". In the book "learning about organization form an orderly universe" (Wheatley 2010)suggested that there should be harmony in the participation by all communities, countries, organization and should take up "change". "Leadership that get results" (Goleman 2000) stated that best Leadership style can be learned as they are a right blend of different styles, used in the right amount and targeted at the right time. Leaders who are able to build a learning environment must articulate ideas, pay optimum attention to understand the infrastructure in which they function and the unambiguous understanding of the fact that leaders must also 'change'. It is also pointed out that the 
bigger challenge of systematic change requires a mix of different people in different positions, who lead in different ways "The fifth Discipline (Peter 1990) the Art and Practice of the Learning Organization". The area of leadership has evolved over the period of time, new and improved leadership style are being investigated and the ideological transformation leadership can be learned and developed in the domain of management. These leaders inspire, energize and intellectually stimulate their employee. Bernard. M. Bass in his expert contribution "Biography and the Assessment of Transformational Leadership at the World class level" (Bass 1990)

Those management practices which can be considered most effective in the area of learning organizations entails that a leadership which empowers employees, encourage a culture of experimentation and having strong commitment with the organizational goals can prove to move the organization to the path of success (Goh 1998).

"Leadership that gets result" (Goleman 2000) concludes, business environment is continually changing, and a leader must respond, in kind. Hour to hour, day to day, week to week, executives must play their leadership role like producing the right one at just the right time and in the right measure the pay off is in the results. "Leaders are designers, teachers and stewards. These roles require new skills: the ability to build shared vision, to bring to the surface and challenge prevailing mental models and to foster more systematic thinking. In short, leaders in learning organizations are responsible for building organizations where people are continually expanding their capabilities to shape their future.... That is leaders are responsible for learning" (Senge and Sterman 1992).

\section{Methodology}

The target population of this study was mandatory to be the organizations from both, manufacturing and service providing sector. The objective of the study is to compare, contrast and analyze whether leadership in these sectors play a vital role to make them 'learning', where these organizations lack and then recommendations would be given to improve and attain competitive advantage. To serve this rationale one organization from each sector is selected on the basis of convenient sampling. Human resources at all levels of board-top-level, middle-level, and frontline - are considered the framework of sample, from both organizations. The entire number of surveyed population is 100. Questionnaire developed by David A. Garvin et al is used as the instrument of follow a line of investigation. Formerly the toolkit contained three parts covering all three building blocks, which included actions of leadership and processes of learning along with the environmental component, but only the part which contained the questions about leadership that reinforces learning is taken to the carry out this research. This kind of customization is allowed from the developer of the scale (Ali, Bajwa et al.). Leadership that reinforces learning is a composite of both concrete learning processes and supportive learning environment. Respondents were reluctant to respond negatively asked questions mostly in the service providing organization whereas; in manufacturing sector organization the respondents were more expressive to share their views. It was made sure that respondent's independence and secrecy is maintained and their ambiguities were tried to be resolved.

\section{Variables and Analysis}

The study of "leadership that reinforces learning" in education sector and manufacturing sector is considered most important building block and researched as its pervasiveness is felt in every sector of the economy of Pakistan. In order to make the study less vast and more oriented to the higher strata of organizations the other two building blocks are neglected in this research.

Our research will take into consideration the following elements of leadership as pivotal in the determination of degree of leadership role to make an organization 'learning'

- Modeling desired behavior

- Open minded questioning

- Thoughtful listening

- Consideration of multiple options

- Acceptance of multiple point of views

All the above elements of leadership that reinforces learning can be measured through different variables used in the survey. The data is collected using a total number of eight Items covering above mentioned five areas of leadership that reinforces learning

\section{Result Interpretation}

After looking into the scores of both manufacturing sector and service sector they are found to lie in the bottom quartile provided by David A. Garvin. It is therefore interpreted that there is a great need of initiating serious efforts to bring improvements in the area of leadership. As leadership is an amalgamated block of both concrete learning processes and supportive learning environment, it is further suggested that elements of the other too building blocks are compulsory to reinforce effective leadership in organizations either operative in 
services or manufacturing concerns. The results reveal that services sector is even poorer in projecting the leadership hence, opening a new vignette for researchers to bring fourth a practical solution to this handicap for learning.

Question wise Mean

Using five point scale, the divisor was five.

Strongly Agree $=1$, Agree $=2$, No Idea =3, Disagree $=4$, Strongly Disagree $\quad=5$

* Reverse Score Question

\begin{tabular}{|c|c|c|}
\hline & Manufacturing & Services \\
\hline Q1 Mangers Invite input from Others? & 38.8 & 23.2 \\
\hline $\begin{array}{l}\text { Q2 May Managers acknowledge their own limitations with respect to knowledge, } \\
\text { information, or expertise? }\end{array}$ & 50.8 & 20.8 \\
\hline Q3 My Managers asks probing questions? & 36.4 & 30 \\
\hline Q4 My Managers listen attentively? & 43.6 & 24.4 \\
\hline Q5 May Managers encourages multiple points of view? & 38 & 46.8 \\
\hline $\begin{array}{l}\text { Q6 May Managers provide time, resources, and venues for identifying problems and } \\
\text { organizational challenges? }\end{array}$ & 48.4 & 49.6 \\
\hline $\begin{array}{l}\text { May Managers provide time, resources, and venues for reflecting and improving } \\
\text { on past performance? }\end{array}$ & 51.2 & 37.8 \\
\hline Q8* My Managers criticize views different their own? & 41.2 & 33.6 \\
\hline Grand Mean & 44 & 33 \\
\hline
\end{tabular}

Industry wise comparison

Q1. In manufacturing sector more managers invite input from others then services sector.

Q2. In manufacturing sector more managers acknowledge their own limitations with respect to knowledge, information, or expertise then services sector.

Q3. In manufacturing sector more managers ask probing questions then services sector.

Q4. In manufacturing sector managers listen attentively then services sector.

Q5. In manufacturing sector managers extensively encourages multiple points of views then services sector.

Q6. In manufacturing sector managers heavily support provide time, resources, and venues for identifying problems and organizational challenges then services sector.

Q7. In manufacturing sector managers seriously Managers provide time, resources, and venues for reflecting and improving on past performance then services sector.

Q8. In manufacturing sector a smaller amount of managers criticize views different their own

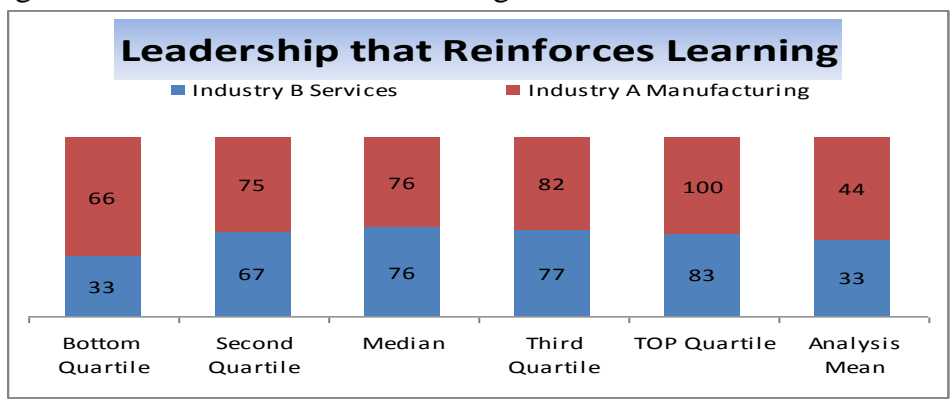

References

[1] Ali, Q., S. U. Bajwa, et al. "Supportive Learning Environment: A Comparison between Private and Public Sector Organizations of Pakistan."

[2] Argyris, C. (1977). "Double loop learning in organizations." Harvard Business Review 55(5): 115-125.

[3] Bass, B. M. (1990). "From transactional to transformational leadership: Learning to share the vision." Organizational dynamics 18(3): 19-31.

[4] Dumaine, B. (1994). "Mr. Learning Organization." Fortune.

[5] Eraut, M. (1995). "Schon Shock: a case for refraining reflection-in-action?" Teachers and Teaching: theory and practice 1(1): 9-22.

[6] Garvin, D. A., A. C. Edmondson, et al. (2008). "Is yours a learning organization?" Harvard Business Review 86(3): 109.

[7] Goh, S. C. (1998). "Toward a learning organization: The strategic building blocks." SAM Advanced Management Journal 63: 1522.

[8] Goleman, D. (2000). "Leadership that gets results." Harvard Business Review 78(2): 78-93.

[9] Nel, C. (2007). "Leadership: the primary driver in high performance organisations." Management Today: 24-26.

[10] Peter, S. (1990). "The fifth discipline." The Art \& Practice of Learning Organization. Doupleday Currence, New York.

[11] Senge, P. M. and J. D. Sterman (1992). "Systems thinking and organizational learning: Acting locally and thinking globally in the organization of the future." European Journal of Operational Research 59(1): 137-150.

[12] Slater, S. F. and J. C. Narver (1995). "Market orientation and the learning organization." The Journal of Marketing: 63-74.

[13] Wheatley, M. J. (2010). Leadership and the new science: Discovering order in a chaotic world, ReadHowYouWant. 